\title{
Símbolo e acontecimento na poesia de Orides ${ }^{1}$ \\ ALCIDES VILLAÇA ${ }^{I}$
}

"Se vens a uma terra estranha curva-te"

1 POESIA de Orides Fontela compõe um sentimento de Destino e uma lucidez serena. ${ }^{2}$ Essa base estoica encontra seu equivalente expressivo numa pureza de formas tão cultivada que ao leitor desconcentrado parecerá talvez fria, talvez asséptica. O engano se revelará logo se dê aos poemas de Orides toda a atenção que exigem. Logo saberemos, e sobretudo sentiremos, que aquela composição custosa vem do fundo da poeta, e em absoluto não elide os traços da paixão e do lirismo - antes os requalifica no perfil sóbrio, econômico e disciplinado que é o seu contorno vital. A falta de um confessionalismo imediatista ou sentimental é deliberação dessa poesia que nos busca em outro plano de confidência: aquele em que se despoja do peso das circunstâncias para se interrogar, serenamente, quanto ao nosso destino. Estou falando da aplicação sensível e reflexiva dessa poesia que atravessa a múltipla qualidade das vivências para avaliar o sentido delas numa perspectiva quase impessoal, que seria metafísica não fosse tão poética, que seria abstrata não se fundasse num sistema simbólico tão expressivo. Chegados ao lugar-comum de que essa poesia vive da construção de seus símbolos, é preciso expandir aquela afirmação inicial: que significa compô-los com fatalismo e lucidez?

“Os fados guiam a quem se deixa levar, arrastam a quem resiste." Essa súmula estoica de Sêneca condiz em parte com a atitude mental que norteia a poesia de Orides, mas não dá conta justamente do que se traduz como construção poética daquela atitude. O criador, por definição, não "se deixa levar": leva-se a si mesmo, tanto quanto é capaz de conduzir sua expressão própria por um caminho que escolheu. É certo que Orides não opõe ao Destino qualquer convicção contrária ou rebelde; mas também é certo que, no círculo de consciência em que se inscreve o movimento da fatalidade, dá-lhe a resposta mais altiva: a perspectiva de sua tradução humana, iluminada em símbolos límpidos, propriedade nossa que devolve aos deuses o arrefecimento da tragédia imposta, no registro sereno que transforma o peso do castigo em lastro de sabedoria. Trata-se, por exemplo, de extrair da Natureza dada cifras da própria consciência íntima que dela se aproxima ou se separa segundo os impulsos próprios da percepção sensível. "Pássaros”, “fontes”, "luzes”, “águas”, “pedras”, “frutos”, "flores" e "peixes" não se impõem como símbolos já marcados, nem tampouco 
são eleitos pela graça imanente: desvestidos da mais fácil "naturalidade", surgem como que desentranhados de um imaginário em tudo original, tal pela primeira vez estivessem anunciando sua eternidade. Dito de outro modo: fixam-se para sempre numa ordem poética para a qual parecem ter nascido, ou como se nela tivessem encontrado a versão mais fiel de sua estabilidade natural. Parecem: nos reiterados espelhos de Orides não se esquece nunca dessa fatalidade imitativa da arte, imediatamente aceita como um outro aspecto do Destino, que a poeta interroga com ânimo sereno. Seria difícil definir o que é contorno afetivo do objeto figurado e o que é consciência pura nessa representação. Essa dificuldade costuma decorrer da poesia mais alta.

\section{As epígrafes: um roteiro}

Para irmos particularizando aos poucos o caminho poético de Orides, consideremos as tão sugestivas epígrafes de seus livros, utilizadas com o mesmo rigor e iluminação que orientam os poemas. A do volume inaugural - Transposição (1969) - são versos da autora:

A um passo de meu próprio espírito

A um passo impossível de Deus.

Atenta ao real: aqui.

Aqui aconteço.

São expressões em tudo localizadoras, dentro de um espaço cujo sentido geométrico se confunde com o sentido simbólico. Tão forte quanto o inefável balizamento indicado por "espírito" e "Deus" é o que se materializa em "a um passo" e "aqui". Dessa permuta nasce aquela fusão de proximidade e distância, tão característica do plano poético: "A um passo impossível”. A identificação entre o "real" e o "aqui" tanto denuncia o posto por assim dizer físico da atenção do $e u$ quanto sua qualidade simbólica, na medida em que esse posto é também o próprio locus das palavras: o poema. Da mesma forma, em "Aqui aconteço" traduz-se tanto a natural corporeidade do existir quanto o seu "acontecimento" fundado na condição de também acontecer (revelar-se momentaneamente) a poesia. É essa que aproxima a poeta de seu próprio espírito e lhe permite ponderar a distância infinita que a separa de Deus. Todas as ambivalências convergem para o fato garantido de que o $\mathrm{eu}$ acontece e, acontecendo, cria a perspectiva a partir da qual se definem a medida desse "passo", a proximidade do próprio espírito e a distância invencível de Deus: a perspectiva da palavra "aqui", do "aqui" da palavra - ela mesma um acontecimento. A epígrafe cola-se com justeza ao título do livro, ao sentido de transposição - termo igualmente espacializante, capaz de abrigar tanto o movimento físico de um a outro ponto quanto a natureza das operações simbólicas. Não seria impróprio concluir que a poesia de Orides aqui expressa a inclinação crucial para reconhecer a distância que separa alma e consciência: transposição que culminaria, sublimada, na comunhão do existir com o sentido mais profundo do ser - comunhão só imaginável no hic et nunc de cada palavra, de cada poema a cada vez em que tudo acontece. Esse 
termo, aliás, restringe bastante a pura veleidade filosófica da busca do Ser; antes parece adensar a ordem natural, o destino universal em que cabe ao sujeito consciente enunciar a própria qualidade do seu acontecimento. Dura condição e duro limite? É que, na perspectiva estoica, "a palavra real/nunca é suave".

A epígrafe do segundo livro - Helianto (1973) - são versos de cantiga de roda:

Menina, minha menina

Faz favor de entrar na roda

Cante um verso bem bonito

Diga adeus e vá-se embora

Foi provavelmente com ouvidos de menina na brincadeira de rua que Orides fixou esses versos; qual sua atualização na poeta de Helianto? Descartada de pronto a pura dimensão nostálgica, a que sua poesia é tão resistente, cabe ler as cifras de que as chamadas "cantigas infantis" são misteriosamente ricas. Há aqui também um acontecimento, dessa vez perfeitamente referido em sua efemeridade: os gestos de se entrar na roda, cantar e ir-se embora. Não haverá talvez fórmula mais econômica para traduzir, com entonação despojada e serena, a brevidade com que cada um assume seu lugar central, desempenha seu papel na vida e... desaparece. Quando o papel é precisamente "cantar", adensa-se outra vez o "aqui" do canto, seu caráter celebratório no registro passageiro. O "verso bem bonito" dá sentido à entrada na roda, e sua beleza inclui a fugacidade do momento, reencenando à aparição de cada cantor. A "roda", na infinita circulação, admite óbvia leitura simbólica; mas a continuar por especulações prefiro concluir: Orides terá fixado desses versos não só a insuspeita emanação trágica, mas sobretudo a naturalidade que se imprime tanto na aceitação dos passos simbólicos da roda absorvente quanto na alegre inflexão que lhes dão as crianças a cantar. $\mathrm{O}$ que não impede, evidentemente, que a nossa própria leitura da cantiga, modulada pela apropriação de Orides, identifique comovida uma profunda humildade.

Em Alba (1983), o terceiro livro, há duas epígrafes. A primeira cita San Juan de la Cruz:

Que bien sé yo la fuente

que mana y corre,

aunque es de noche.

A segunda é da própria autora:

A um passo

do pássaro

res

piro.

A convicção expressa nos versos do místico espanhol é forma poética da certeza doutrinária de que "lo spiritual excede al sentido, y com dificultad se dice algo de la sustancia del espíritu si no es com entrañable espiritu" (apud Guillén, 
1983, p.86). Desmembramento desses versos o leitor de Orides encontrará em momento do poema "Murmúrio", desse mesmo livro: "O murmúrio não cessa. Nunca a/fonte/deixará de cantar/oculta [...]".

$\mathrm{Na}$ segunda epígrafe retorna aquela ideia de "a um passo", da epígrafe de Transposição, agora em fórmula mais sintética e sonoramente mais unificada, imitativa ainda da respiração suspensa ("res/piro"), a sugerir no ritmo a pulsão de um corpo tornado presente... aqui. Em ambas, como também nos versos do poeta espanhol, acentua-se a presença/ausência do "real", a distância mas também a proximidade do sujeito: sempre a perspectiva fundante do eu que acontece em meio a acontecimentos, do eu que tangivelmente respira a intangibilidade do pássaro a um passo. Nessas sucessivas localizações líricas, não seria difícil aproximar a qualidade da distância avizinhada (entre o sujeito e o real) da qualidade do silêncio expressivo que tantas vezes se põe entre as palavras.

A epígrafe de Rosácea (1986) é de Heráclito:

Coisas varridas e

ao acaso

mescladas

- o mais belo universo

Explica-se a própria Orides, num depoimento:

[...] organizei o livro depressa demais, e o material era bem heterogêneo.

[...] Justifiquei-me usando como epígrafe um koan de Heráclito, isto é, se o universo é uma bagunça organizada, um "caosmos", meu livro também poderia ser a mesma coisa, tranquilamente $[\ldots] .^{3}$

Mas parece haver mais que uma justificativa na citação de Heráclito. O paradoxo de dispersão e ordem, da união na desunião, de acaso e pontuação contempla a ideia de que os acidentes esparsos ganham por vezes unificação, equilíbrio e beleza, resgatando-se a si mesmos do turbilhão das "coisas" do "universo": um acontecimento raro e preciso que a atenção não pode perder; momento do "verso bem bonito" em que o eu se situa e, inspiradamente, "res/ pira". Não é outra a impressão geral que tenho da poesia de Orides: re-união de momentos iluminados, caprichosa composição a implicar, já além do "acaso", aquela geometria dos cristais que tantas vezes sugerem as formas da poeta, amante de espelhos, rosáceas e heliantos, capaz de revelar na "nossa contingência" o "peso essencial do amor profundo".

\section{A transposição}

Até onde se pode chegar com elas, as epígrafes são chaves sugestivas que agem numa obra por dentro e por fora. Também a poesia de Orides se abre e se fecha para nós, ao modo daquelas "flores reticentes" de que fala Drummond. Como não cabe ao leitor resolver os paradoxos do poeta, mas compreendê-los em seu amplo movimento, nossa tarefa é agora reconhecer, tanto quanto pudermos, a natureza e o modo desse movimento. 
$\mathrm{Na}$ origem dele creio que está a conviç̧ão de que a poesia consiste sobretudo em compor, na ordem das palavras, uma percepção que jamais se guardaria fora do símbolo poético. É a tradução simbólica convicta que preside a sensação de se estar "a um passo" de tudo o que é essencial. Impondo-se alguns símbolos essenciais, já aqui referidos, instala-se a poeta no universo deles, e com eles articula a expressão de si mesma, num exercício de transposições em que o eu e seus símbolos espelham-se mutuamente. Mas veja-se que na consciência antirromântica de Orides não há lugar para aquela credulidade que via na operação simbolizante um triunfo absoluto e compensatório, uma efetiva harmonização: nossa poeta acentua, muito modernamente, a distância que vai da palavra à coisa, o silêncio invasor que separa as diferentes naturezas, silêncio "selvagem" e "difícil" de esfinge. Tal consciência faz que Orides tome as palavras como instâncias de uma dolorosa e inevitável mediação para aquilo que, sendo essencial, não deve se decompor no momento da expressão. Resta, "a um passo" de tudo, transpor tudo para o cristal do espelho: "cristal único estéril/mar em branco".

Transpor, mediar, seria isto... esterilizar? Converter a existência sensível em essência simbólica não traz o risco de insuportável abstração para a poesia? Sim, se o percurso for de mão única e não nos obrigar, como ocorre nos poemas de Orides, ao retorno dialético: o essencial é também real, e aliás só existe enquanto depuração da qualidade mesma dos acontecimentos. O símbolo vive, como se sabe, de sua natureza dinâmica, de um movimento que a rigor nunca termina entre o que ele apresenta e o que ele faz significar. Como a poesia de Orides vive sobretudo da ação dos símbolos - ação quase exclusiva e incontrastada -, decanta-se nela uma realidade simbólica tão unificada que se torna, a seu modo, vivencial: um acontecimento, entre outros. Falar os símbolos equivale, aqui, a vivê-los; simbolizar, aqui, é viver um acontecimento completo em seus próprios limites.

Tal operação implica uma tendência radical: a conversão do sujeito ele mesmo num símbolo, no maior de todos, no mais ativo e fundante. Naquele gesto de "desnudar a estrela essencial / sem ter piedade do sangue", quem sangrará: a estrela ou a poeta? Ainda que esta se confesse, no poema "Rosa", como a assassina do nome da flor ("Eu assassinei a palavra / e tenho as mãos vivas em sangue"), fazendo crer que é da flor que flui a vida, no poema "Fala" tudo é tão "agressivamente real" que "nos despedaça" (grifo meu). Em "Torres": “o real / nos doerá para sempre"; em "Mãos": "as mãos se ferindo / nos seres, arestas / da subjacente unidade"; em "Ludismo": "Quebrar o brinquedo ainda / é mais brincar". Tudo faz pensar em uma só dor, fatalizante no trânsito do ser para as coisas e destas para o ser, fatalizada em todo acontecimento, e fatalizável enquanto possível conbecimento. É o que parece se contrair na admirável síntese do verso final de "Meio-dia": "A vida é lúcida e impossível" - em que o Acontecimento maior ("vida") se desdobra na conquista de uma iluminação ("lúcida") e na dor da falta de sua plena vivência ("impossível"). 
O livro Transposição está organizado em quatro momentos: em I-Base, este termo, entre arquitetônico e musical, expressa, de fato, um fundamento, tal o de um alicerce, tal o de uma tonalidade básica; são poemas que falam da criação e do jogo poéticos, da desejável geometria, da transparência da palavra, do trançar e do destrançar, do laboratório e do experimento, do aprender e do tatear; em $I I-(-)$, o conceito da subtração e da perda casa-se bem com o tom menor em que os poemas cantam sobretudo a dor, a crueldade, o impasse que marcam o "não saber não saber não saber não saber" de cada acontecimento, enfatizando o intervalo de silêncio que medeia o objeto e sua expressão, tornando o sujeito um "ser perdido / em vozesfragmentos" e deixando patente "a inútil crueldade / da análise"; mas em III - (+), a adição e o ganho, afinados pelo tom maior, lembram a possibilidade repentina de lucidez, da "imor / talidade do instante", de "fixação tranquila", de "céu apreendido" e de momentos para sempre mágicos, como aquele em que "o girassol me escolhe" e se faz "flor para sempre e muito mais / que flor"; e em IV-Fim há tanto uma síntese conclusiva dos momentos quanto uma especulação teleológica: é o que está em "Questões", na pergunta fundamental: "o / fruto / arquitetado: / como o sermos?" - pergunta que encena o movimento essencial da poesia deste livro: transpor-se o ser na intimidade dos símbolos que durem para sempre, em esforço de - mais do que adotar uma máscara - erigir-se tal uma "estátua jacente" que "habita / tempos não sabidos / de mortos e vivos".

Em Transposição o movimento básico é de ascese e queda alternadas, jogo de ganho e perda, vivido de fato a cada poema e habilmente estruturado na sequência das partes. Há em tudo uma lógica de ferro, que facilmente desembocaria num conceptualismo prosaico ou filosofante não fosse a extraordinária sedução do ritmo preciso e dos símbolos iluminados, plano afetivo em que se enraizam e de que brotam, transfiguradas, as questões existenciais - parcelas que somam uma só epifania, um mesmo acontecimento. Neste, pressente-se seu antes e seu depois: antes, a experiência ainda bruta e sem espelho, um anseio físico, uma confusão dolorosa, um querer falar; depois, o passo impossível, a infinitude e a morte, o silêncio vencedor, o "branco arcaico em torno / do nada”. Entre ambos, o acontecimento fixa-se em seus limites, de onde pode mesmo interrogá-los no tom paradoxal de uma serena voluptuosidade, que faz pensar na tradução feita por Manuel Bandeira (1966, p.414) dos versos de Rilke ("Epitáfio"): "Rosa, ó pura contradição, volúpia / De ser o sono de ninguém sob tantas / pálpebras". Entre o limite da experiência empírica e o do desconhecido, Orides concentra "o amor, momen / to do ser refletido / eternamente pelo espírito". A soma de tantos instantes de "lucidez breve" integra a efemeridade numa sequência, o achado poético numa poesia contínua, o símbolo singular num logos revelador, a circunstância da criatura no acontecimento da criação. Criação que pode mitigar a sede implícita em "Rebeca": "A moça de cântaro e seu / gesto essencial: dar água”. 


\section{O helianto}

Se os poemas de Transposição em tudo materializavam o movimento que está no título do livro, há pouco analisado, os de Helianto sugerem antes um movimento circular, que está na epígrafe (a cantiga de roda), na rotação do girassol (helianto) e sobretudo no modo como as palavras parecem fechar-se em torno de si mesmas, desenhando o alvo do poema como um "centro exato dos círculos / concêntricos". Nesse "ritmo em círculo", Orides empreende uma "arquitetura / corforma do possível", elabora em plena geometria um "abstrato vitral / das figuras do ser". Como que a serviço de alguma iconografia, as palavras apresentam-se o mais materialmente possível, deslocando-se no espaço da página, grafando-se em maiúsculas ou negrito, citando-se a si mesmas entre aspas, verticalizando a leitura do poema, exigindo lúdicas paronomásias. Contudo, se o jogo é ostensivo e virtuosístico, há mais do que ele. De modo mais travado, por vezes mais artificial, subsiste aquela busca de fixação, como se lê nos versos "Fixar estrelas / no mapa móvel / zodíaco" (aqui com um sutil humor de paródia de Bilac), no intuito de "submeter os astros / à palavra". É como se a poeta renunciasse ao movimento típico da transposição, mas não esquecesse das duas pontas dele - o ser e a palavra -, que agora busca atar em círculo. Deus, que antes lhe dava a sensação do "a um passo do impossível", é agora a palavra "Deus", entre aspas, apresentado com um "Cubo / de metal opaco". Pergunta-se a poeta: "Onde a fonte?" - para responder, no mesmo poema: "Vasos aguardam / pacientes". Orides está a fixar os "claros signos", tarefa em que parece segura mas que igualmente lhe dá a sensação de que "lentamente o tempo / perde-nos" e de que "sofremos a hora intensa". A certeza desses limites arrebata das construções luminosas qualquer júbilo de artesã, projetando sobre o indiscutível domínio técnico dos signos espacializados uma sombra de desconfiança quanto ao tempo que dura "um verso bem bonito".

O maior tecnicismo de Helianto, que a poeta mesma reconheceu no depoimento já referido como "maestria" mas também "limitação" de quem agora circula em metapoesia, parece descarnar os símbolos de sua complexidade maior, e as formas do real surgem mais planas e menos densas. É sintomática a pergunta "Mas para que serve o pássaro?", que se alonga em outra: "De que serve o pássaro se / desnaturado o possuímos?”. A "desnaturação" parece corresponder aqui não à perda da natureza própria, mas da capacidade de se apresentar um símbolo de forma essencial, com uma aura de vida perfeitamente compartilhável pelo sujeito lírico. Alçando-se num voo meio mallarmaico, "as asas de / neve / buscam o / branco / cume perfeito", sugestivamente deixando "A terra muito / abaixo. / Muito abaixo o odor do sangue" - sangue, lembremo-nos, que em Transposição fluía entre o corpo da poeta e a imagem tocada.

Há, de novo, ganho e perda: a lucidez ganhou em fixar-se numa espécie de luz própria das palavras, explorando-as no limite da verbalidade, considerando-as com o zelo próprio de um linguista ou de um artesão que se exercita nas fer- 
ramentas; a perda, sempre ameaçadora mas nunca total, é a do lírico sentimento de Destino que recortava em cada instante a mortalidade pungente, a finitude que se queria transpor. Felizmente, nem sempre Orides se livra aqui da terceira dimensão dos nomes e das coisas. No belíssimo "Sete poemas do pássaro", ela refoge das inquirições em tom de exercício e coloca um de seus símbolos prediletos em sete perspectivas, numa das quais define de forma vital a transfusão de energia entre o cantor e o cantado: "Nunca saberemos / tanta pureza: / pássaro devorando-nos / enquanto o cantamos”. Denso é também esse jogo de perguntas que podemos surpreender entre duas estrofes de dois poemas contíguos: a primeira é de "Escritura":

Ó forma

violenta pura

como emprestar-te algo

humano

uma vivência

um nome?

A segunda é de "Forma":

Forma

densamente forma

como revelar-te

Esse jogo não deixa dúvida quanto à fundação do sujeito no acontecimento pleno, no habitar as próprias palavras e ganhar delas aquele preciso "saber que a boca prova".

\section{A alba}

Em Alba volta a poeta a posicionar-se "a um passo de", como já se definira em Transposição. Mas a "volta" é requalificada por um peso maior no "aqui", por uma revitalização do ser mesmo do sujeito, ser mais ativo e corpóreo, mais senhor da simbolização e mais maduro em sua humanidade. Esse livro é o que parece melhor ilustrar a "definição" de poesia que Orides formulou de modo alegórico e original:

A poesia era uma jovem num jardim encantado, e um serviçal seu é que escrevia e "enviava", sei lá como, os poemas para o poeta. Isso não é melhor nem pior que muito papo por aí... (in Massi, 1991, p.257)

Essa "teoria", nascida ao tempo em que a poeta ainda frequentava o Grupo Escolar (!), supõe a origem inefável, uma laboriosa fatura escrita e o "envio" ao poeta... que a tudo imaginou. A fórmula simples (mas nada simplória) considera, pois, a instância transcendente da Poesia mesma, que até hoje ninguém definiu, o trabalhoso medium em que ela se encarna e a existência mesma dos poetas em cuja tradição também nos humanizamos.

Alba guarda o tempo todo uma tonalidade religiosa muito particular, 
muito pessoal, qua já supõe o contexto até então da obra poética de Orides. Em muitos momentos esse livro parece ser uma antítese de Helianto e um aprofundamento de Transposição. A antítese está numa nova "sideração" da poeta pelo sentido do tempo e do Destino, mais determinante que a busca do controle espacial da palavra; o aprofundamento pode ser reconhecido na madura serenidade com que os símbolos já familiares (pássaros, fontes, estrelas...) se organizam sob o influxo de mitos, lendas, memórias, ritos, verdadeiramente renascendo, religando-se a algum ponto genesíaco ("abri os olhos [...] como da primeira vez"), cumprindo uma rota de depurações (nunca suficientes) e desembocando, quase em purgação apocalíptica, naquele "Letes" final "que nos limpa de todas / as palavras". A particular religiosidade de Alba (luz e renascimento) habita a entonação mais grave e decidida dos poemas e se dá a ver no apego da poeta por não importam quais crenças ou mitologias que tenham, no entanto, legado imagens fortes de alguma paixão, esteja ela no sacrifício de Prometeu, no trabalho de Penélope, na ação dos trovões, na vigilância das Parcas, no eterno retorno dos pássaros, na simbologia do vinho, na fulminância dos raios, na sinalização da árvore, na "hora dos peixes", na beatitude dos anjos imóveis. Os primeiros versos do livro anunciam um fiat nada bombástico, na verdade íntimo, de luz que "entra furtivamente" e "surpreende o sonho inda imerso / na carne". A fusão iluminada de "sonho" e "carne" reatualiza aquele "aconteço" de Transposição num mais anímico "res / piro". No percurso, o livro vai acentuando a claridade ("alvo seio", "céu dourado", "luz branca") até atingir o "branco centro / da vertigem" e o "branco espelho" - luz intensíssima e depuração máxima: saudação ao Destino cujo "rio subterrâneo" se faz, enfim, "fonte", e "nos limpa de todas / as palavras".

Se em Transposição o movimento expressivo lembrava um ir e vir algo linear entre o ser e os símbolos, e entre esses e o "real"; se em Helianto a figura estruturante era a do círculo autorreferente - em Alba a perspectiva mítico-temporal sugere a espiral e se explicita em "ciclos", como na estrofe de "Ode":

Não há fim nem início. Sem história

o ciclo dos dias

vive-nos.

Nos versos acima está, como em todo o livro, o aguçamento da interpretação fatalista, na qual reponta um prazeroso estoicismo. A comoção dos poemas surge e instala-se em nós de forma muito depurada, própria de um convívio estreito do sentimento em princípio trágico com a sábia sobranceria da consciência. Sente-se nesse livro sem traços biográficos que a pessoa da poeta amadureceu para si mesma, e com ela os seus símbolos, dilatados no poder de aludir e organizados num sistema ainda mais íntegro e coerente. Decorrerá talvez disso, a par do sentimento do Destino implacável, uma pacificação profunda do sujeito, que em certo momento ganha mesmo o raro sentido de uma satisfação: "Reteso o arco e o / sonho / espero: nada mais é preciso"; "Bebemos profun- 
damente.../ Não é preciso renascer". É como se o momento, o acontecimento se alargasse até uma plenitude; é como se a dimensão vertical daquele "profundamente" furtasse do tempo um outro sentido de eternidade: "ritmo submerso / sem asas para o tempo". Introduzindo-se e quebrando a linearidade simples de Cronos, atua também a memória que, "absorvendo o ímpeto" (dos centauros "que derrubam ídolos"), "floresce". Entenda-se: não os fatos memorizados, mas a memória como dimensão possível do tempo, integrada no circuito mítico em que uma qualidade da vida ancestral perpetua-se no acontecer dessa poeta $\mathrm{e}$ de sua poesia e agirá depois dele, na projeção da eternidade.

Se ainda havia alguma dúvida nos leitores de Transposição e de Helianto, os poemas de Alba consolidarão a atividade de uma poeta para quem a poesia é uma tarefa do espírito, sem qualquer concessão a compreensões outras. Convém insistir em que o grau de depuração de consciência poética de Orides atinge nesse livro o limiar de uma estase, por força de sucessivas e progressivas representações do Absoluto, daquela Poesia que encontra no Rio letal, em sua "água densa" e purificadora, o esquecimento e o silêncio.

Entende-se daí - dessa específica qualificação do silêncio - que os poemas possam ser considerados uma "profanação", função mesma, aliás, dos poetas, que o devem "saber de cor" para "dissolvê-lo / em palavras". Essa noção de poesia como impertinência apoia-se sempre, em Orides, naquela convicção de que está sempre "a um passo de", como aquele pássaro "atento a" - branco de predicação que dessubstancializa o conhecimento ao mesmo tempo em que adensa a espera: movimento teimoso do espírito. É nessa ordem de ideias que se pode avaliar o quanto é fundamental para a poesia de Orides a questão da representação, que transcende o puro plano estético e se confunde com a decifração mesma do Destino - impossibilidade para a qual a Poesia talvez sirva de consolo, ao delinear com precisão nem que seja o perfil de nossas carências. E lembrar como são cruciais e inquietantes as tantas frases interrogativas disseminadas nesta poesia.

Na perspectiva mágica e abismal de $A l b a$, o alvo é claro e enigmático (para lembrar o Drummond da década de 1950): claro pela insistência e unificação dos símbolos, enigmático pela amplitude de sua alusão. Entre as tendências de Alba está a de se buscar uma síntese simbólica, uma imagem única e rara que corresponda integralmente ao movimento da expressão. Ela se insinua em vários momentos, sem que a pluralidade elimine o que em cada uma se projeta como um absoluto. Em "a mão" é a estrela que "subsiste [...] sobre as águas", depois do naufrágio da forma; em "Trovões" é uma flor armada "com o que resta - ainda - / de silêncio"; em "Mapa" ela é a carta dos céus em que "tudo se move". A cada epifania essencial o desafio para o leitor é acompanhar uma espantosa adequação entre os símbolos e os conceitos, o pensamento e sua figuração sensível - desafio de reconhecer tão íntima e solidamente unidos o que o senso comum vive a separar. De fato, parece haver um realismo original nesse 
sistema poético que dá plena realidade ao essencial, que aposta tudo na contínua intensidade de seu jogo, defendendo-se serenamente de uma fácil acusação de impostura mística com a humildade que espelha na finitude humana e na limitação das palavras. Resiste sempre, substancial, o impeto da consciência insatisfeita que encontrou no modo simbólico sua expressão adequada. Tem-se a impressão de que "pássaros", "flores", "pedras", "estrelas"... poderiam ser outros nomes, sem que por isso se perdesse a qualidade essencial dessa poesia, que está muito mais no modo como o sujeito articula os predicados de seus objetos do que nos objetos em si mesmos. Uma heresia poética? Melhor será dizer: um afastamento da qualificação hegeliana de arte romântica e uma realização de um modo artístico outro - "clássico"? - em que a paixão intervenha sem compromisso com a exaltação ou com a ênfase na distintiva individualidade.

Similar ao trabalho de Penélope, a poesia de Alba arma-se e desarma-se como ao compasso de um pêndulo entre o sim e o não, entre o ser e o não ser, movimento que tanto aprimora o fruto quanto a fome. Sente-se nela o trabalho lento, a atenção cuidadosa para com os fenômenos do existir, a reflexão incansável, o contato amoroso com as palavras, seus ritmos, sua sonoridade, sua precisão, sua abertura para o inefável; mas todo esse labor não se ilude quanto ao Tempo misterioso, quanto ao movimento contínuo de que cada acontecimento não é senão um recorte e um lampejo; quanto à Morte, que preside a essa poesia com o efeito de um baixo contínuo, a lembrar-lhe o humilde limite. É diante da Morte e a despeito da Morte que se consagra o paradoxo dessa poesia; é dessa coragem que ela está investida, e com ela funda seu próprio modo de ser radicalmente... viva.

Imagem de "alba": esforço de claridade que inclui a renovação constante, um reacontecer, um refazer absolutamente não ocioso, já que seu caminho clarificado inclui a compreensão nossa e a viagem comum. Talvez melhor dizer: a Viagem, para fazer jus ao horizonte dessa poesia e acolher com empatia sua orgânica aspiração.

\section{A rosácea}

De seu livro mais recente - Rosácea - salta à vista a composição mais heterogênea: "coisas novas, fundo de gaveta e restos de memória", como depôs Orides (in Massi, 1991, p.260). Não está desfeito, em todo caso, aquele "clima" poético das obras anteriores; ele persiste, acrescido agora de um aspecto novo e modulante: uma órbita de nomes próprios e de fontes culturais, artistas, pensadores, familiares, que deixam entrever uma herança histórica e um discreto círculo doméstico - órbita na qual se refaz o permanente exercício de transposição, a operação transfiguradora em que todo acontecimento adquire uma aura essencial. Drummond, Bandeira, Mário Quintana, e Kant, Pascal, Roussseau, a Bíblia, e a avó, o pai, a mãe, a irmã natimorta - são referências de maior ou menor peso, mais ou menos rápidas, que, no conjunto, situam indicialmente a leitora de filosofia, de poesia e a "herdeira" de família pobre. Menos que um 
rosto, mas já uma atitude nova de quem se permite alguma parcela de identificação "externa". Pode-se especular sobre as futuras expansões desse veio lírico mais próximo do biográfico; se seria esse um desafio presente para sua poesia; se essa mais visível "concretude" virá a ser alguma notável contrapartida dialética do essencialismo em que sempre mergulharam os poemas; se, enfim, estará nesse rumo a "nova virada, a mais problemática de todas" de que fala a poeta. O que nos cabe, enquanto Orides decide seu caminho, é ainda reconhecer seu último passo, nesta Rosácea.

$\mathrm{Na}$ sequência do livro há uma sugestiva utilização de tempos que parecem correr em sentido contrário. Há o tempo progressivo, correndo a partir daquela "aurora" homérica do poema de abertura, tempo que vai acolhendo referências à pirâmide egípcia, ao Velho Testamento, que parece organizado em função da "iniciação" da poeta na "terra estranha" da Poesia, tempo das experiências de leitura, da aquisição de uma mitologia pessoal, de uma refacção de falas e escrituras (o "anti-César", o "anti-Gênesis", o "Esconjuro" de deusas, bruxas e heroínas), de apropriações de filósofos - tudo lembrando um movimento cumulativo de formação que desemboca nos poemas datados de década de 1960. E há o tempo inverso, materializado na sequência que vai dos poemas "novos" da primeira aos "antigos" da última seção do livro, previsto para se chamar... Rosácea. Se essas considerações não são de todo ociosas, pode-se deduzir delas um sentido já avaliatório que estaria dando Orides a um ciclo definido de sua poesia, como também, a partir delas, vem reafirmada a livre movimentação de consciência poética por tempos de qualidade vária.

Cifra importante dessa poesia encontra-se nos versos de "Iniciação", que cito por inteiro:

Se vens a uma terra estranha

curva-te

se este lugar é esquisito

curva-te

Se o dia é todo estranheza

submete-te

- és infinitamente mais estranho

O tom aconselhador e declaratório, tão pretensioso ou leviano em discursos sem lastro, mescla-se aqui com aquela humildade sábia de quem atenta para o próprio labirinto antes de acusar a tortuosidade alheia. Inclui-se no poema a lembrança, sempre oportuna, de que a "estranheza" tantas vezes imputada à poesia nasce da falácia de quem quer se dar como padrão de naturalidade, cego que está para a sua própria condição de "estrangeiro" num mundo "natural"... que não sabe explicar. $\mathrm{O}$ reconhecimento (também um autorreconhecimento) de que "és infinitamente mais estranho" será oportuno também para aquele que, diante dessa poesia em particular (atente-se para o emprego do verbo vir, 
e não $i r$ ), julga-a "estranha" por descurar do cotidiano, por não lançar-se em rocamboles experimentais, por não afirmar um preciso vetor ideológico - enfim, por teimar em ser o que é: essencialmente viva, inquiridora e lúcida. O poema reafirma ainda a vocação da estoica profecia de quem antevê o "extenso silêncio" confirmar-se no tempo, na pedra que sempre cairá sem "nenhuma interrogação"; vocação do observador que, a cada pedra que cai, a cada acontecimento, "sorri / tranquilamente".

Os poemas classificados como "Lúdicos" (segunda seção do livro), alguns epigramáticos, "visitações" outros, repelem, por trás do aspecto e do tom mais leves, qualquer concessão ao barateamento do anedótico, da paródia frívola. Ao corte de humour junta-se sempre a cifra do destino, em roupagem mais desambiciosa que não disfarça um mergulho essencial. Em "Anti-César" ("Não vim. / Não vi. / Não havia guerra alguma.") fica patente o avesso do herói ou do dito célebre, transmudados na aceitação de fatalidade sem batalha, da severa resignação. Em "CDA (relido)" -

Caio ver

ticalmente

e me transformo.

- o corte súbito nos versos originais de "Morte no avião", do poeta mineiro, afasta a exterioridade de "em notícia" e radica a "transformação" no interior do próprio sujeito, requalificando-se imediatamente os termos "caio" e "ver / ticalmente" na dimensão poética própria de Orides.

Também os poemas "Bucólicos" (terceira seção) remontam à andança pastoril para simular um locus amoenus em que, no entanto, os pássaros parecem libertar-se da moldura, a sede é "ácida" demais para a "água / tão breve" e o que se semeia é o movimento mesmo de passar daquele que, sem olhar para trás, declara: "não me importa a colheita".

Dos "Mitológicos" já nem é preciso dizer que se trata, sempre, do gesto geral de apropriação - que pode recair sobre a "esfinge" -

Não há perguntas. Selvagem

o silêncio cresce, difícil.

- quando, mais forte que o enigma esperado, é a mudez branca e sem rosto de um Destino desinteressado. Outro nome para esse Destino pode estar em "Ananke" (no grego: necessidade), quando se considera que, no arranjo providencial e ordenador dos fados, "Não há culpa / não há desculpa / não há perdão." - ordem que inspira o reconhecimento, não o julgamento.

Da última seção - "Antigos" - ressaltam os sonetos, todos datados com precisão, não se sabe se para justificar-se algum envergonhado anacronismo da forma fixa ou para se depor sobre um tempo em que no caderno de poemas havia ainda espaço e disposição para o dia certo dos acontecimentos. O fato é que já havia, em 25.10.63, uma "alta agonia" na tarefa de "despir os sortilégios, 
brumas, mitos" para se chegar à raiz da "pureza / de contingência extrema", a caminho do "lúcido fruto". Os leitores de Orides poderão ajuizar quanto à fidelidade àquele caminho e ao amadurecimento do fruto.

Para concluir esta passagem por Rosácea, um retorno aos "Novos" e uma rápida parada em "Herança" - um poema sobretudo inesperado. Inesperado porque surgem sem aviso, nessa poesia avessa a qualquer identificação civil, a avó materna, o pai, a mãe e certa "herança" familiar. As figuras surgem como que a desprender-se, com seus objetos, de um quadro cuja materialidade não cerceia a sugestão dos símbolos, tomados aqui numa concentração máxima de referência concreta e capacidade alusiva:

Da avó materna

uma toalha (de batismo)

Do pai:

um martelo

um alicate

uma torquês

duas flautas.

Da mãe:

um pilão

um caldeirão

um lenço.

A leitura desse poema perde muito caso não a sustente o contexto mais amplo da poesia de Orides, que pode servir como uma espécie de predicação necessária à cadeia de nomes que o estrutura. Da associação imediata dos parentes com os objetos legados deve projetar-se uma outra, informada por uma poética particular. Assim é que aquela toalha de batismo da avó pode resumir toda uma ancestralidade humilde, símbolo depurado das origens confundidas com a pobreza e com o rito religioso que, mais do que cristão, parece perder-se nos tempos. Da mãe e do pai herdam-se, em primeiro lugar, ferramentas e utensílios de trabalho de operário e da dona de casa, sugerindo-se o esforço das mãos e o peso da matéria a ser batida, torcida, socada, desencravada, revolvida. Ao universo do trabalho acopla-se um outro, o plano mais íntimo e afetivo das "duas flautas" do pai (canto, timbre doce, sensibilidade) e do lenço da mãe (lágrima? suor? aceno? luxo de pobre?). De dupla natureza, o inventário, paupérrimo num sentido, tem em outro a sugestão para aquela economia do essencial que a imprevista poesia da herdeira transpôs no trato requintado da linguagem culta: sólido compromisso com um repertório básico de símbolos essenciais e com sua projeção poética num universo cujo "luxo" está na iluminação do despojamento. A "herança tem o peso material da pobreza e a carga imponderável dos afetos que convergem na toalha de batismo, nas flautas, no lenço - junção que é também própria dos símbolos. Da herança recebida ao poema "Herança" manteve-se um princípio de 
despojamento da casa pobre e das palavras poucas, e se o transpôs como lastro de uma nova condição existencial. Ao fado da casa rústica sucederá o da "Casa lúcida, habitada / de denso vazio vivo" - a edificação poética de Orides.

\section{A teia}

O último livro de Orides - Teia (1996) - frequenta a intensidade dos livros anteriores, reunidos em Trevo (1988), e nesse sentido não é surpreendente que a poeta continue, como é próprio da linguagem poética, a fazer do reconhecimento das coisas uma surpresa ou dotar de impacto um símbolo milenar. A falta de novidade - essa prestigiosa embalagem de tanto produto descartável - de modo algum nos dispensa de repensar a qualidade de revelação desses poemas derradeiros.

Não será com os ouvidos aturdidos que trazemos da rua que perceberemos a precisa densidade do silêncio de onde essa linguagem mais uma vez se arrancou, para vencê-lo momentaneamente e a ele retornar, a cada vez e sempre. Esse silêncio estruturante, que tanto pede do leitor, apagou quase todos os vestígios da experiência empírica, para que dela só ficassem a vibrar uns poucos estímulos essenciais, convertidos, como de hábito na poesia de Orides, nos símbolos necessários à contraída expressão de um ser no mundo. Esse silêncio, quebrando a inteireza do verso tradicional e suprimindo as cadências mais fáceis do canto, insinua-se entre as palavras e expressões segmentadas, nos vãos construídos pelos fios da teia-armadilha onde nós, como presas, decantamos as questões da vida e aprendemos a morrer. Lição prevenida da morte, o silêncio de Orides requalifica os símbolos essenciais numa economia estoica, de quem se determinou um tão lacônico como fundo testemunho.

As seis partes do livro dão discreta mobilidade e respiração ao conjunto. Seus títulos sugerem o modo de exposição ("Fala"), o procedimento construtivo ("Axiomas" e "Figuras"), a sinalização dos símbolos ("O Anti-pássaro") e as inflexões dominantes ("Galo (noturnos)" e "Vésper (finais)", de cada elenco de poemas. A unir tudo, a constante do sentimento do destino, cuja expressão exercitada tem a força de uma justificativa única, exclusiva da vida que o sujeito poético guardou para espelhar a si mesmo. Mas quem é ele? Protegido por silêncios e resistente ao prosaico, velando a rotina e os impulsos naturais, só nos deixa conhecer a trabalhada síntese de um saber rapidamente projetado na imagem que serve à ideia ("Casulo"), num tempo sem duração ("Flores"), numa invocação ao vazio "Prece"), num retorno ao enigma ("Narciso (jogos)"). Sabemos, porém que a poesia é a figura que permanece, é o tempo qualificado, é a fala com destino, é o mistério a formalizar-se. Nas cifras de Orides, antes de tudo belas, adivinha-se a dor expungida e a perspectiva implícita: trata-se de uma fala constituída numa natureza intensa da mulher, com dicção afinada pelo tempo moderno.

Sim: fala de mulher. Em Teia são recorrentes as imagens da espera altiva, da gestação, da metéria subterrânea, da luz soterrada, do ser encasulado, da 
vibração oculta - figurações cujo específico pathos parece, ao mesmo tempo, imantado pelo telurismo feminino (mais exigente e mais radical que o realismo masculino) e projetado numa tela mítica rarefeita (menos idealista do que aquela em que se movem os guerreiros épicos, os patéticos quixotes, os gauches, os visionários construtores. Refiro-me à absorção da vida como experiência de uma energia atávica, que uma Clarice Lispector (não por acaso presença forte em um dos poemas) tantas vezes constituiu como o minério das minuciosas escavações femininas. A fala de mulher da poesia de Orides parece brotar dos momentos de uma gestação para sempre contida numa promessa sem fruto, qualificando o lugar da espera como uma já-realização, como um já-acontecimento. As figuras do círculo e do espelho tornam-se básicas: assim se reinterpreta o mito de Narciso: "A fonte / deságua na própria fonte".

Os signos de Orides têm lastro e prospecção. Lê-se em "Cartilha": "Foi de poesia / lição / primeira: / a arara morreu / na / aroeira": como não surpreender aqui a fusão do jogo didático das cartilhas com a emanação misteriosa das palavras que sensibilizaram para sempre a menina de escola? Sua arte refina-se nesses limites desafiadores, com lições de emoção seca e funda. Seus versos buscam uma "nudez / até o osso / até a impossível / verdade", cristalizando um projeto poético em que o drama silenciado e a matriz formalizante indiciam-se mutuamente. Supõem, a princípio, a tradição moderna, mas acabam por constituir uma sua contraface ao mesmo tempo primitiva, intemporal e sofisticada, camada essencial a que chegou essa rigorosa arqueóloga de si mesma. A palavra do sujeito poético pode ser recolhida como também nossa, e nesse acolhimento os símbolos de Orides ganham seu sentido histórico. Se não me engano, a qualidade poética desses pássaros e dessas pedras, desses anjos e desses metais, só se deixa apurar num plano mais fundo da consciência sensivel; não é banal que alguém o frequente e nele se expresse, em pleno fastígio da vida barateada e materializada.

\section{Uma síntese}

Sem bairrismo, sem regionalismo, sem nacionalismo; à margem de "vanguardas"; imune à parodização como sistema; sem biografismo, sem confessionalismo, sem psicologismo; sem expansão retórica, mas sem minimalismo triunfalista; fora do anedótico, do panfleto, da provocação; sem bandeira política, estética ou ecológica; sem escatologia agressiva, dramatismo ou ressentimento em que águas, afinal, navega ou lança âncora a poesia sem rótulo de Orides? Os que carecem de algum talvez recorram a "metafísica", ou "neossimbolista" ou mesmo "neoclássica"; mas assim como é justo reconhecer que são as etiquetas que devem servir aos produtos, mais justo será que façamos um esforço último para a compreensão dessa poesia.

A primeira afirmação dela é a da notável liberdade com que se afasta das "tendências históricas" acima, ou de qualquer limitada noção de História: liberdade que tem a consciência de retirar das experiências vividas uma suma 
qualitativa, um sentido último que se faz primeiro, um saber imediatamente identificado com seu expressar mais justo, e só neste vivo. A leitura atenta dos versos de Orides não deixará de intuir, nos subterrâneos, as fontes vivenciais do sentimento de Destino: a recusa em admitir o "drama pessoal", a nenhuma alusão quanto à ordem do empírico, a repulsa pela marca de fogo do senso comum, a impossibilidade de se viver no puro conforto/desconforto do corpo. A entonação serena e a forma despojada, o léxico básico repetido mas nunca inócuo, os símbolos de luz, fluxo e estabilização - tudo recobre com alguma transparência aqueles subterrâneos, promovendo o diálogo da fatalidade com seu domínio expressivo. Tão viva em seus íntimos círculos de luz, a poesia de Orides supõe sempre a morte, incluída aliás no sentido mesmo daquela iluminação: erupção e apagamento de cada epifania, brotar e fenecer de cada acontecimento, brilho ativo e branco silencioso em que mergulha cada poema. Trata-se de figurar, por cima das avulsas contingências e da experiência das rupturas, um nexo simbólico entre os valores essenciais, tal pudessem os poemas constituir, em sua soma, uma cadeia de luz ininterrupta. Não podem: a poeta o sabe. Na finitude mesma das palavras, das imagens, dos símbolos, explora-se a convicção de que a proximidade calorosa com o "essencial” dos seres e das coisas guardará sempre "um passo" dele, dessa suspeita de Verdade que movimenta a consciência. A poesia de Orides supõe a universalidade desse movimento, e quer acompanhá-lo dentro de si mesma porque verá nele alguma solidarização vital. $\mathrm{O}$ trabalho do poema lírico, como se sabe, é exatamente esse, e nenhum outro o substitui nessa função,

Se ainda fosse preciso (talvez para evitar equívocos bem maiores) ligar a persona poética de Orides a alguma figura mais identificadora, lembraria, pela constância e pela intensidade de seu trabalho poético, bem como por aquele parco sentido que a poeta the dá no interior de seus critérios essencialistas, a figura de Sísifo interpretada por Camus (1942, p.164): "La clairvoyance qui devait faire son tourment consomme du même coup sa victoire".

\section{Notas}

1 Este ensaio, com o mesmo título, foi em parte publicado na revista Novos Estudos Cebrap, n.34, em novembro de 1992. Acrescentou-se a parte dedicada ao livro Teia, último de Orides, publicada no Jornal de resenhas (Discurso editorial / USP / Unesp / Folha de S.Paulo) eml2 de julho de 1996.

2 Seus cinco livros estão editados no volume Orides Fontela - Poesia reunida [19691996] (Fontela, 2006).

3 Ver depoimento "Nas trilhas do trevo" (in Massi, 1991).

\section{Referências}

BANDEIRA, M. Estrela da vida inteira - Poesias reunidas. "Poemas traduzidos". Rio de Janeiro: José Olympio, 1966. 
CAMUS, A. Le mythe de Sisyphe. Paris: Gallimard, 1942.

FONTELA, O. Orides Fontela - Poesia reunida [1969 - 1996]. São Paulo: CosacNaify; Rio de Janeiro: 7 Letras, 2006 (Coleção Ás de colete, v.12).

GUILLÉN, J. Lenguaje y poesía. "Lenguaje insuficiente - San Juan de la Cruz o lo inefable místico". 3.ed. Madrid: Alianza Editorial, 1983.

MASSI, A. (Org.) Artes e ofícios da poesia. Porto Alegre: Artes e Ofícios, 1991.

RESUMO - A poesia de Orides Fontela se afasta com notável liberdade de inflexões dominantes da modernidade. O que sobretudo a caracteriza, além de seu rigor formal extremo, é a interrogação permanente sobre o nosso destino e a figuração de nexos simbólicos entre as experiências vividas e sua projeção transcendente.

PALAVRAS-CHAVE: Orides Fontela, Poesia contemporânea, Símbolo poético, Estoicismo ABSTRACT - The poetry of Orides Fontela departs with remarkable freedom from the dominant inflections of modernity. Besides an extreme formal rigor, its foremost trait is the permanent questioning of our destiny and the portrayal of symbolic nexuses between the experiences one lives and their transcendental projection.

KErwords: Orides Fontela, Contemporary poetry, Poetic symbol, Stoicism.

Alcides Villaça é professor titular de Literatura Brasileira da Faculdade de Filosofia, Letras e Ciências Humanas da USP. @- acvillaca@uol.com.br

Recebido em 21.11.2014 e aceito em 10.12.2014.

${ }^{\text {I }}$ Faculdade de Filosofia, Letras e Ciências Humanas, Universidade de São Paulo, São Paulo/São Paulo, Brasil. 